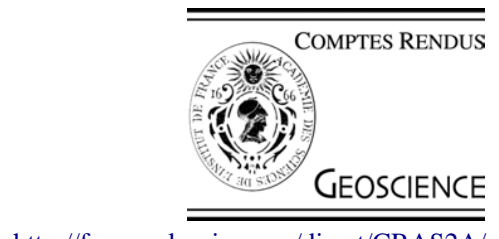

http://france.elsevier.com/direct/CRAS2A/

Tectonics / Tectonique

\title{
Estimation of subsidence using GPS measurements, and related hazard: the Pingtung Plain, southwestern Taiwan
}

\author{
Chin-Shyong Hou ${ }^{\text {a,b }}$, Jyr-Ching Hu ${ }^{\text {b }}$, Li-Chung Shen ${ }^{\text {b }}$, Jing-Suei Wang a \\ Chien-Liang Chen ${ }^{a}$, Tien-Chang Lai ${ }^{a}$, Chung Huang ${ }^{b}$, Yi-Rong Yang ${ }^{b}$, \\ Rou-Fei Chen ${ }^{\mathrm{c}}$, Yue-Gau Chen ${ }^{\mathrm{b}}$, Jacques Angelier ${ }^{\mathrm{d}, \mathrm{e}, *}$ \\ a Central Geological Survey, MOEA, P.O. Box 968, Taipei, Taiwan, ROC \\ b Department of Geosciences, National Taiwan University, Taipei, Taiwan, ROC \\ ${ }^{\mathrm{c}}$ Institute of Earth Sciences, Academia Sinica, Nankang, Taiwan, ROC \\ d Observatoire océanologique de Villefranche-sur-Mer, université Pierre-et-Marie-Curie, Géosciences Azur, \\ BP 48, 06234 Villefranche-sur-Mer cedex, France \\ e Institut universitaire de France, 103, bd Saint-Michel, 75005 Paris, France
}

Received 8 April 2004; accepted after revision 20 April 2005

Written on invitation of the Editorial Board

\begin{abstract}
Four years of GPS measurements were done since 1996 in southwestern Taiwan in order to investigate crustal deformation and land subsidence. The network of 48 stations revealed the velocity field in the Pingtung Plain. Horizontal velocities range from 31 to $54 \mathrm{~mm} \mathrm{yr}^{-1}$ towards azimuths $247^{\circ}$ to $273^{\circ}$. They show clear anti-clockwise deviation in the coastal area, consistent with tectonic transtension related to lateral escape at the transition collision-subduction. The deformation resembles a particle flow towards a free boundary, and is not a rigid rotation. Vertical velocities range from +13 to $-25 \mathrm{~mm} \mathrm{yr}^{-1}$. Twenty stations show fast subsidence in the coastal area, with rates averaging $-16 \mathrm{~mm} / \mathrm{yr}$. The comparison with Holocene subsidence suggests that about $75 \%$ of the present-day subsidence result from decreasing groundwater level induced by over-pumping, adding significant short-term component to the natural risk resulting from long-term tectonic subsidence. To cite this article: C.-S. Hou et al., C. R. Geoscience 337 (2005).
\end{abstract}

() 2005 Published by Elsevier SAS on behalf of Académie des sciences.

\section{Résumé}

Estimation de la subsidence à partir de mesures GPS et risque associé : la plaine de Pingtung, Sud-Ouest de Taiwan. Quatre années de mesures GPS ont été faites depuis 1996 au Sud-Ouest de Taiwan, afin d'analyser la déformation crustale et la subsidence. Le réseau de 48 stations a révélé le champ de vitesses de la plaine de Pingtung. Les vitesses horizontales vont de 31 à $54 \mathrm{~mm} \mathrm{an}^{-1}$ vers les azimuts $247^{\circ}$ à $273^{\circ}$. Elles montrent une déviation antihoraire dans la région littorale, en accord

\footnotetext{
* Corresponding author.

E-mail address: jacques.angelier@1gs.jussieu.fr (J. Angelier).
} 
avec la transtension tectonique liée à l'échappement latéral dans la zone de transition collision-subduction. La déformation n'est pas une rotation rigide, mais se compare plutôt à un flux de particules vers le sud-ouest. Les vitesses verticales vont de +13 à $-25 \mathrm{~mm} \mathrm{an}^{-1}$. Vingt stations révèlent une subsidence rapide de la région côtière. Comparée à la subsidence holocène, la subsidence actuelle résulte pour $75 \%$ de la baisse de niveau des nappes d'eaux souterraines par pompage excessif, accroissant dans l'immédiat le risque naturel dû à la subsidence tectonique à long terme. Pour citer cet article $:$ C.-S. Hou et al., C. R. Geoscience 337 (2005).

(C) 2005 Published by Elsevier SAS on behalf of Académie des sciences.

Keywords: GPS geodesy; Lateral escape; Subsidence; Pumping; Hazard; Taiwan

Mots-clés : Géodésie GPS ; Échappement latéral ; Subsidence ; Pompage ; Risque ; Taiwan

\section{Version française abrégée}

\section{Introduction}

Une subsidence due au pompage des eaux souterraines a été caractérisée dans de nombreux pays [5, $17,18]$, y compris Taiwan [3,6,15], où l'industrie et l'aquaculture en ont fait un usage intensif depuis les années 1970 [16]. Le pompage excessif a causé des dégâts dans des régions côtières de Taiwan, où il a provoqué une subsidence entraînant inondations et dégradation d'infrastructures. À Taiwan, la superficie affectée par ce type de subsidence a dépassé $1890 \mathrm{~km}^{2}$, dont environ 10347 ha [4] dans la plaine côtière du district de Pingtung (données de 1959-1985).

Le nivellement géodésique est ordinairement utilisé pour la surveillance de la subsidence. La géodésie satellitaire, particulièrement le GPS, est devenue un outil de valeur pour de telles études. Un vaste réseau peut être analysé périodiquement, par exemple une ou deux fois par an. La déformation inter-sismique actuelle de la zone de convergence de Taiwan a été étudiée grâce au «réseau GPS de Taiwan », comprenant 141 stations, analysées 4 à 6 fois de 1990 à 1995 [19]. En 1999, le séisme de Chichi a mis en évidence la complexité et la dualité de la frontière de plaques de Taiwan [1].

La couverture par le réseau GPS de Taiwan était trop lâche pour permettre une bonne quantification à des échelles de 1 à $10 \mathrm{~km}$. Un réseau spécifique a donc été implanté depuis 1996 dans les régions de Kaohsiung et Pingtung. Il permet de déterminer la déformation crustale d'origine tectonique, associée à la subsidence locale due aux pompages. Dans cette note, nous analysons la déformation et la subsidence de la plaine de Pingtung (Fig. 1) en fonction des résultats non publiés de relevés GPS de 1996 à 1999. Nous cherchons ainsi à caractériser l'effet du pompage, qui a de notables implications pour la prise en compte du risque lié à la subsidence.

\section{Cadre tectonique et géologique de la région de Pingtung}

Le Sud-Ouest de Taiwan correspond à la transition entre la subduction, au sud, et la collision, au nord (Fig. 1). Le bassin plio-pléistocène d'avant-pays y est lié à la flexure lithosphérique qui accompagne la surcharge tectonique de la chaîne centrale [14]. La plaine de Pingtung, de forme rectangulaire, occupe $1210 \mathrm{~km}^{2}$. C'est un bassin empli de sédiments non consolidés du Pléistocène supérieur et de l'Holocène. Les sédiments sont principalement des sables et boues côtiers et estuariens, avec des coquillages et Foraminifères de mer peu profonde ou de lagune. À l'ouest, des collines de sédiments quaternaires déformés bordent la plaine de Pingtung. À l'est, cette plaine s'arrête contre les montagnes de la chaîne centrale, constituées de roches tertiaires métamorphiques. Au sud, elle s'ouvre sur le détroit de Taiwan.

Le trait géomorphologique le plus frappant de cette région est l'escarpement rectiligne nord-sud de la faille de Chaochou, entre la plaine alluviale et la montagne. À l'est de cette faille, la chaîne centrale montre des schistes et quartzites d'âge Éocène à Miocène. Autour de cette zone de faille de Chaochou a eu lieu dans le temps une évolution de la transpression vers la transtension, vraisemblablement liée à la transition collision-subduction qu'accompagne une extrusion vers le sud-est $[11,12]$.

\section{Le réseau GPS de Pingtung}

Le réseau GPS de Pingtung (Fig. 2) fut implanté en 1995 par le Service géologique central du mi- 
nistère des Affaires économiques, afin d'analyser la déformation actuelle et la subsidence dans la région de Pingtung-Kaohsiung. Ce réseau comprend 48 stations temporaires et une station permanente. Entre août 1995 et août 1999, les mesures de stations GPS temporaires ont eu lieu de 3 à 4 fois.

Les variations de distance entre stations ont permis de calculer les vitesses relatives des stations GPS. Lors de chaque campagne, des mesures simultanées ont été faites par groupes de quatre à huit stations, chaque station étant active pendant plus de deux sessions de 6 à $14 \mathrm{~h}$ chacune. Toutes les données ont été analysées avec le logiciel GPS de l'université de Berne (Suisse) [9]. Les distances vont de 3 à $21 \mathrm{~km}$ et sont pour la plupart inférieures à $10 \mathrm{~km}$. Les résultats sont résumés en termes de vecteurs de vitesses moyennes sur les Figs. 2 et 3.

\section{Résultats et discussion}

Ces campagnes GPS ont permis de caractériser le champ des vitesses de déplacement du Sud-Ouest de Taiwan par rapport à la station permanente de Paisha, située sur la marge continentale (Fig. 1). Les vitesses horizontales vont de 31 à $56 \mathrm{~mm} \mathrm{an}^{-1}$, vers les azimuts $245^{\circ}$ à $273^{\circ}$ (Fig. 2). La signification à long terme de telles mesures «instantanées » (sur une période de 4 ans), en fonction du cycle sismique est un problème habituel, bien illustré par le séisme de Chichi en 1999 [1]. Les informations de sismicité historique et de paléosismicité sont rares dans la plaine de Pingtung, en partie à cause d'une activité sismique bien moindre que dans plusieurs autres régions de Taiwan. Par ailleurs, les mesures GPS révèlent la déformation au voisinage de la surface. Certains facteurs superficiels, comme la présence d'épaisses formations argileuses (par exemple, la formation Gutingkeng) au Sud-Ouest de Taiwan, peuvent jouer un rôle additionnel, mais l'ampleur et la répartition des déformations soulignent le rôle majeur de l'extrusion crustale.

La distribution des vecteurs est étonnamment régulière (Fig. 2). Ces vitesses horizontales décroissent vers l'ouest et tendent à croître vers le sud. Bien que les directions des vecteurs s'ajustent fort bien sur de petits cercles concentriques centrés au sud de Taiwan, la distribution des vitesses suffit à éliminer l'hypothèse d'une rotation rigide (qui exigerait une croissance des vitesses vers le nord, au contraire de ce qui observé).
La distribution des vecteurs évoque donc un flux de particules vers un domaine libre au sud-ouest, plutôt qu'une rotation de blocs rigides.

Un contraste cinématique marqué ressort de cette distribution : les stations GPS se déplacent vers l'ouest pour la partie centrale et occidentale du domaine d'étude, mais elles sont nettement déviées vers le sudouest pour la région côtière de Kaohsiung (Fig. 2). Comme l'ont souligné $\mathrm{Hu}$ et al. [7,8], cette déviation antihoraire des vecteurs de mouvement est liée à une déformation de type transtensif, qui reflète l'augmentation vers le sud de l'extension le long des piedmonts méridionaux de la chaîne de Taiwan, dans la zone de transition entre collision et subduction.

La distribution des mouvements verticaux issue de nos mesures GPS (Fig. 3) permet d'éclairer les modalités de la subsidence, donc d'évaluer les risques qui l'accompagnent. Dans la région étudiée, les vitesses verticales vont de +13 à $-25 \mathrm{~mm} \mathrm{an}^{-1}$ (vitesse vers le haut positive). La distribution des résultats délimite deux régions, au nord avec soulèvement, au sud avec subsidence (Fig. 4). Dans la partie méridionale de la plaine de Pingtung, les vitesses de subsidence, soutenues, vont de -11 à $-25 \mathrm{~mm} \mathrm{an}^{-1}$. La plus forte vitesse est la même que celle calculée auparavant d'après des relevés de géodésie conventionnelle de 1914 à 1979 [2]. Cette rapide subsidence est en partie la conséquence du pompage généralisé d'eaux souterraines pour l'aquaculture. Tenant compte d'une récente étude des changements de niveau des nappes d'eaux souterraines [10], nous attribuons donc la subsidence totale de la partie méridionale de la plaine de Pingtung à la combinaison de deux phénomènes : un basculement tectonique régional vers le sud-ouest et le pompage des eaux souterraines. Nous ne connaissons malheureusement pas l'éventuelle variation saisonnière des mouvements, puisque les quatre campagnes GPS ont eu lieu en juillet-août. Les stations GPS permanentes permettront de répondre à cette question à l'avenir, de même que d'autres techniques, comme l'interférométrie radar.

La reconstitution des mouvements verticaux antérieurement au pompage permet de séparer ces effets. Lai et al. [13] ont déterminé des taux de subsidence holocènes dans la plaine de Pingtung méridionale, grâce à des datations radiométriques et des analyses de carottes de forage. Ils ont conclu à une vitesse moyenne de subsidence de $4 \mathrm{~mm} \mathrm{an}^{-1}$ environ, la plus rapide 
subsidence se faisant dans l'axe de la plaine près de la côte, comme c'est le cas actuellement (Fig. 4). Cette subsidence holocène dans la plaine méridionale de Pingtung est deux à six fois moins rapide (quatre fois en moyenne) que la subsidence actuelle indiquée par nos mesures GPS de 1996 à 1999.

La subsidence actuelle résulte à la fois de la baisse du niveau des nappes d'eaux souterraines dans la plaine côtière de Pingtung et de la poursuite de la déformation de type transtensif qui accompagne l'extrusion tectonique au Sud-Ouest de Taiwan. Admettant que la composante tectonique de la subsidence est demeurée à peu près la même, nous concluons que la contribution des pompages à la subsidence de cette plaine méridionale de Pingtung se monte à environ $12 \mathrm{~mm} \mathrm{an}^{-1}$ en moyenne, soit le triple de la subsidence d'origine tectonique ( $4 \mathrm{~mm} \mathrm{an}^{-1}$ en moyenne).

\section{Conclusion}

Quatre années de mesures GPS montrent que la déformation horizontale de la région PingtungKaohsiung est dominée par une association entre transtension et extrusion tectoniques. Par rapport à une station permanente du plateau continental, les vitesses horizontales des stations vont de 31 à $54 \mathrm{~mm} \mathrm{an}^{-1}$ vers des azimuts $247^{\circ}$ à $273^{\circ}$ (Fig. 2). L' accroissement vers le sud de la déformation en extension s'accorde bien avec l'hypothèse d'échappement latéral. Le soulèvement domine dans le Nord de la plaine de Pingtung (jusqu'à $+13 \mathrm{~mm} \mathrm{an}^{-1}$ ), en harmonie avec la collision de Taiwan. Vingt stations de la partie sud de cette plaine témoignent d'une subsidence rapide au voisinage de la côte (Fig. 4) : $-16 \mathrm{~mm} \mathrm{an}^{-1}$ en moyenne et jusqu'à $-25 \mathrm{~mm} \mathrm{an}^{-1}$. La comparaison avec les taux de subsidence holocènes (environ $-4 \mathrm{~mm} \mathrm{an}^{-1}$ dans la même région) suggère que cette subsidence résulte pour environ $75 \%$ de la baisse des nappes d'eaux souterraines, à cause d'un pompage excessif. L'intervention humaine accroît donc significativement le risque naturel issu de la subsidence tectonique associée à l'échappement latéral en terminaison méridionale de la chaîne de collision de Taiwan.

\section{Introduction}

Land subsidence resulting from groundwater withdrawal has been observed in many regions $[5,17,18]$, including Taiwan $[3,6,15]$, where groundwater has been the main source of water supply, or a substitute of surface water, for aquaculture and industry since the seventies [16]. Over-pumping has thus become a major concern in some coastal regions of Taiwan, where it induced problems of land subsidence, resulting in frequent flooding and infrastructure failure, and hence in serious economical loss. In Taiwan, the total area affected by subsidence because of groundwater pumping has exceeded $1890 \mathrm{~km}^{2}$. In the coastal Pingtung County, the total area affected is about 10347 hectares [4], based on studies from 1959 to 1985.

Geodetic levelling is a common technique for monitoring land subsidence on a long-term basis. Satellite geodesy, especially Global Positioning System (GPS), became a powerful tool for geodetic monitoring over large areas, with acceptable altimetric accuracy during the recent years. Using survey mode GPS, a network of stations is measured periodically, typically once or twice a year. Across the convergent zone of Taiwan, the horizontal present-day deformation of the interseismic stage has been documented by the 'Taiwan GPS Network', with 141 stations surveyed 4-6 times from 1990 to 1995 [19]. The 1999 Chichi earthquake revealed higher complexity and the dual character of the plate boundary zone of Taiwan [1].

The coverage from the Taiwan GPS Network was too sparse to allow good quantification of the deformation at the $1-10-\mathrm{km}$ scale. For this reason, a specific network has been established since 1996 in the Kaohsiung and Pingtung areas. It allows determination of crustal deformation of tectonic origin mixed with local subsidence resulting from groundwater withdrawal. We study herein the deformation patterns and local subsidence in the Pingtung Plain (Fig. 1), based on unpublished data from extensive GPS surveying from 1996 to 1999 . We thus aim at characterising the pumping-related effect, which has severe implications for hazard mitigation.

\section{Tectonic and geological background of Pingtung area}

Southwestern Taiwan is located in the transition zone between subduction to the south and collision to the north (Fig. 1). It corresponds to the southern part of the Plio-Pleistocene foreland basin submitted to 


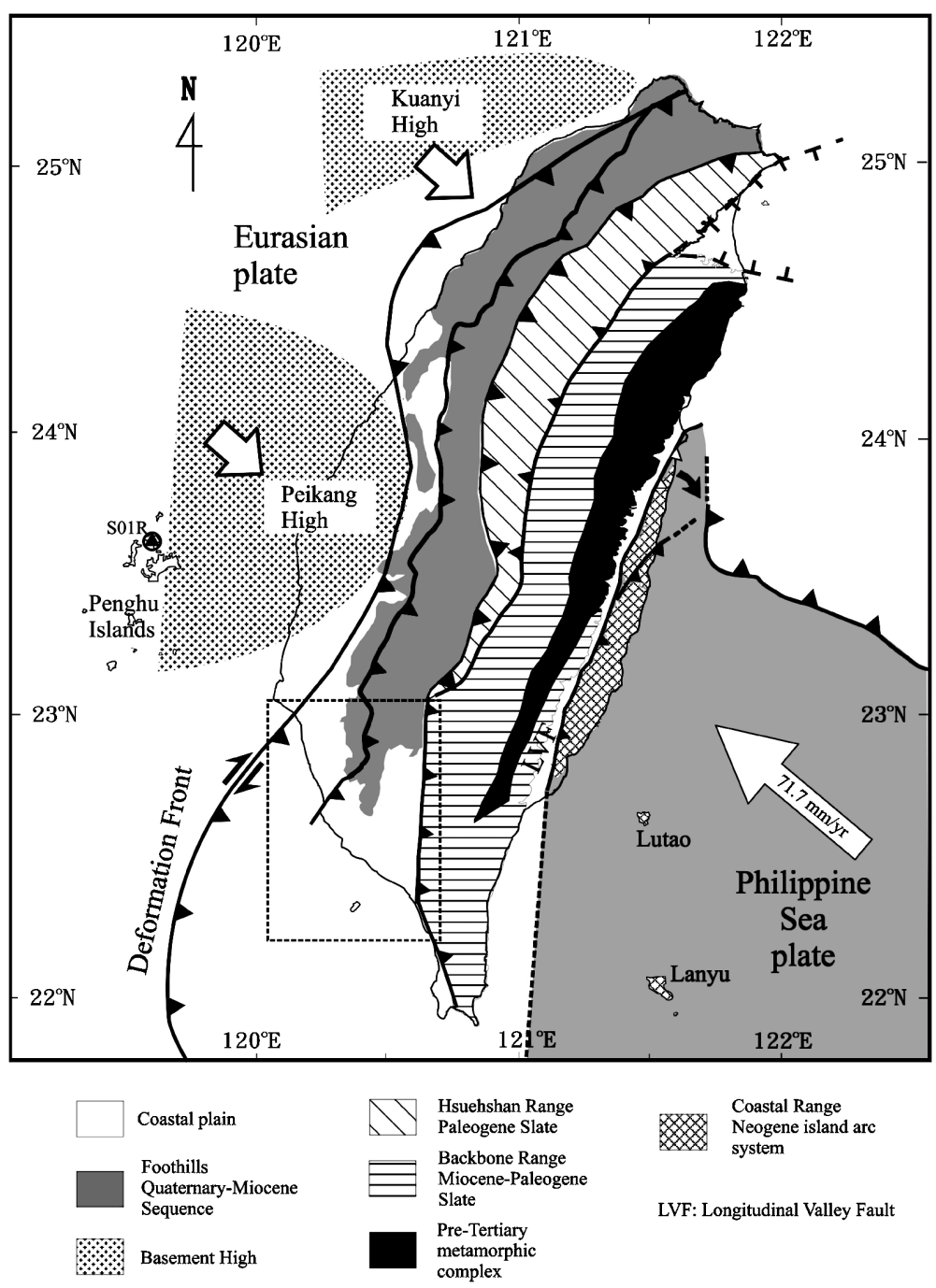

Fig. 1. Tectonic framework and main structural units of Taiwan. Open arrow [19] shows the direction and velocity of plate convergence of Philippine Sea plate with respect to the South China block that belongs to Eurasia. Major thrust faults as thick lines with triangles on upthrust side. Dotted rectangle indicates the study area.

Fig. 1. Cadre tectonique et principales unités structurales de Taiwan. La flèche blanche [19] montre la direction et la vitesse de convergence de la plaques de la mer des Philippines par rapport au bloc de Chine du Sud appartenant à l'Eurasie. Chevauchements principaux en trait gras avec des triangles du côté chevauchant. Le rectangle pointillé indique la région étudiée.

lithospheric flexing that primarily results from the tectonic loading of the Central Range [14]. The Pingtung Plain covers an area of $1210 \mathrm{~km}^{2}$ and in map view exhibits a rectangular shape. Unconsolidated sediments of the Late Pleistocene and the Holocene fill this basin. Most of sediments consist of coastal to estuarine sand and mud, with abundant shallow marine to lagoon shells and foraminifers. To the west, the Pingtung
Plain is bounded by hills of deformed Quaternary sediments. To the east, it is bounded by the central-range mountains, made of metamorphosed Tertiary rocks. To the south, it opens on the Taiwan Strait.

The most significant geomorphological feature of the area studied is the straight, north-south-trending Chaochou Fault escarpment, which separates the alluvium plain and the high mountains. East of the Chao- 
chou Fault, the mountains are mainly composed of Eocene-Miocene argillite, slate and meta-sandstone. A change from transpression to transtension occurred along the Chaochou Fault, probably related to the transition from collision to subduction inducing active extrusion towards the southeast $[11,12]$.

\section{The Pingtung GPS Network}

In order to analyse the present-day crustal deformation and land subsidence in the Pingtung-Kaohsiung area, the 'Pingtung GPS Network' was established in 1995 by the Central Geological Survey, Ministry of Economic Affairs (Fig. 2). It is composed of 48 temporary stations and one continuously monitoring station. Between August 1995 and August 1999, the mobile stations of the network were surveyed 3-4 times with dual frequency geodetic GPS receivers.

The changes in baseline components derived from these GPS measurements provided accurate estimates of the relative velocities of GPS stations in the study area. In each survey, 4-8 stations were observed simultaneously with dual-frequency geodetic receivers

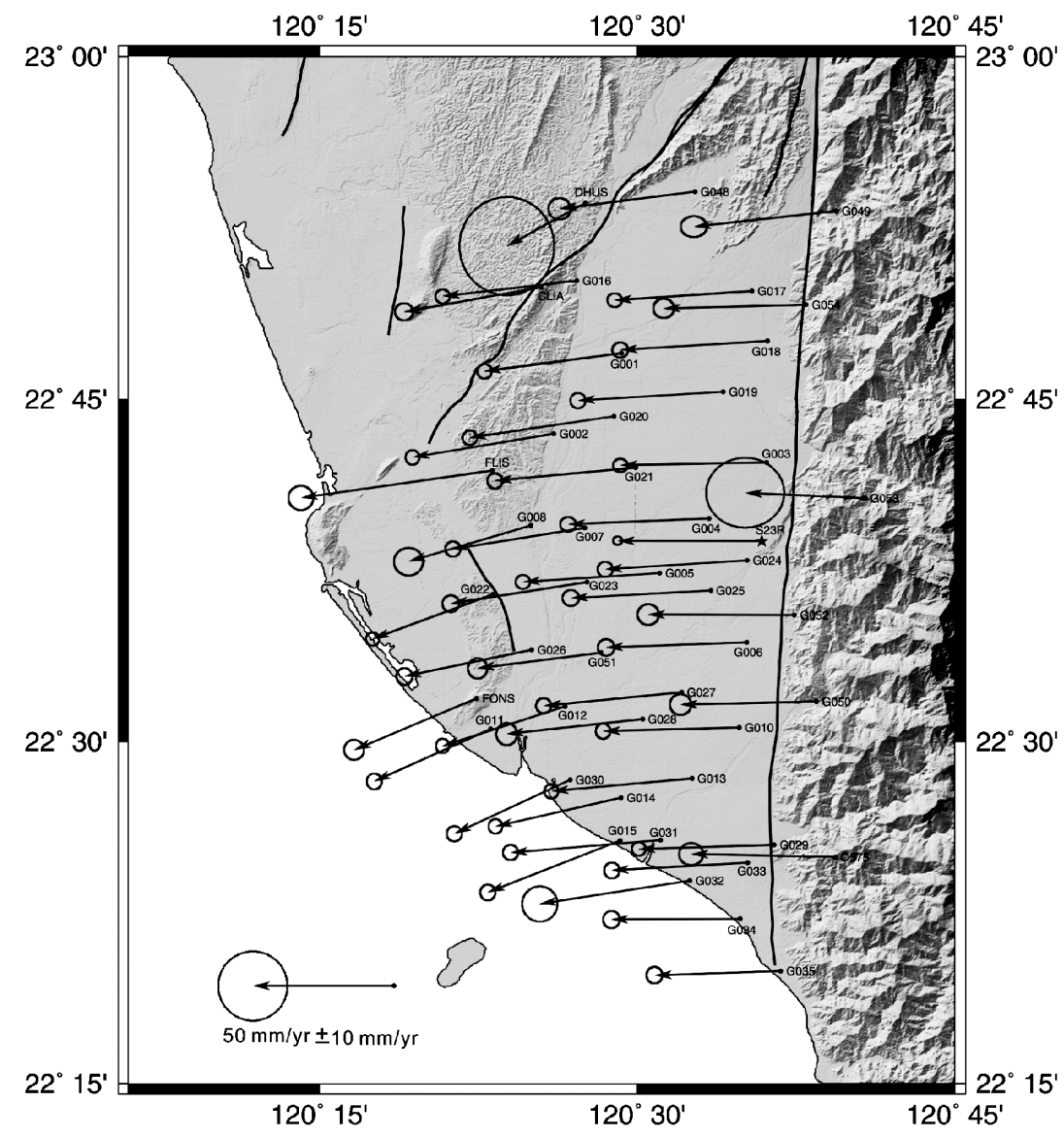

Fig. 2. Horizontal velocity field of GPS stations in the Pingtung Plain area, relative to station in Paisha, Penghu (Fig. 1), from 1996 to 1999. GPS stations as small dots (star for permanent station). The $95 \%$ confidence ellipse is shown at the tip of each velocity vector. Thick lines are active faults. Shaded topography based on the 'Taiwan Digital Elevation Model'.

Fig. 2. Champ de vitesses de déplacement horizontal des stations GPS de la plaine de Pingtung, par rapport à la station de Paisha, Penghu (Fig. 1), de 1996 à 1999. Les stations GPS sont des points (étoile pour la station permanente). L'ellipse de confiance à $95 \%$ est indiquée à l'extrémité de chaque vecteur vitesse. Les traits gras sont les failles actives. La topographie ombrée est issue du «modèle numérique topographique de Taiwan». 
(Trimble 4000 SSE Geodetic Surveyor). A station was usually active during more than two sessions, each session involving 6-14 h of GPS data acquisition from all available satellites rising higher than $15^{\circ}$ in elevation angle. The sampling interval was 15 s. Daily solutions were computed for continuous GPS data. The ionosphere-free linear combination of observations at the L1 and L2 frequencies was employed as the basis for estimating station coordinates and baseline solutions.

We have processed the observed data with the ephemeredes distributed by the IGS. Temporary measurements and continuous records were analysed with the Bernese GPS software (v. 4.2) developed at the Astronomical Institute of the University of Bern [9]. The observed data in each survey epoch were processed session by session to obtain baseline solutions for all couples of stations. The scatter of GPS measurement series over several years gives relative indication on precision. The long-term repeatability highlights the effects of slowly varying systematic errors resulting from propagation delay, multipath or fiducial network inconsistencies.

In the first approximation, assuming steady motion between stations during the four-year period, the scatter of data points was defined relative to a bestfit straight line on the plot of baseline components versus time [9]. The repeatability of baseline component (east, north, and vertical) or baseline length was obtained from the root-mean-square scatter about the linear trend. The baselines range from 3 to $21 \mathrm{~km}$ in length, most of them being shorter than $10 \mathrm{~km}$. The average rates of length change of each baseline between nearby stations, usually observed in the same session, were determined from linear regression in time. The results are summarised in Figs. 2 and 3, in terms of average velocity vectors.

\section{Results and discussion}

The GPS surveys have provided a complete velocity field of SW Taiwan relative to the Paisha permanent station on the continental shelf (Fig. 1). The horizontal GPS displacement velocities (Fig. 2) range from 31 to $56 \mathrm{~mm} \mathrm{yr}^{-1}$, with azimuths ranging from $245^{\circ}$ to $273^{\circ}$. How far such 'instantaneous' measurements (over a period of four years) reflect the long-term deformation is a common problem, well illustrated by the 1999 ChiChi earthquake [1]. In the Pingtung Plain, the data about historical earthquakes and palaeoseismicity are scarce, partly because the seismic activity is low with respect to several other regions in Taiwan. On the other hand, the GPS data reveal the near-surface deformation. Some near-surface features may play an additional role, like the existence of thick mudstone formations in southwestern Taiwan (e.g., Gutingkeng Formation). However, both the amplitude and distribution of the deformation highlight the major role of crustal extension.

The pattern of horizontal velocity vectors shows surprising regularity (Fig. 2). The horizontal station velocities decrease westwards and rather increase southwards. Although their vector trends fit small concentric circles centered south of Taiwan, the velocity distribution contradicts the hypothesis of a rigid rotation (which would imply a northward increase in velocity, inconsistent with our data). The vector distribution thus resembles a particle flow moving towards a free boundary to the southwest, not a motion of rigid blocks.

The pattern of vertical deformation revealed by our GPS measurements (Fig. 3) provides significant issues concerning the subsidence-related hazard. In the studied area, the vertical station velocities range from +13 to $-25 \mathrm{~mm} \mathrm{yr}^{-1}$ (upward velocity positive). The data distribution delineates two distinct regions, north with dominant uplift and south with dominant subsidence (Fig. 4). In the southern Pingtung Plain, rather fast subsidence rates, from -11 to $-25 \mathrm{~mm} \mathrm{yr}^{-1}$, are observed. Our maximum subsidence rate fits the value previously calculated based on conventional geodesy from 1914 to 1979 [2]. This fast subsidence partly results from extensive groundwater pumping for aquaculture. Taking into account a recent study of groundwater table evolution [10], we attribute the total subsidence of the southern Pingtung Plain to two mixed effects: regional tectonic tilting towards the southwest and local groundwater withdrawal. Unfortunately, we have no information about a possible seasonal variation of motion, because the four GPS campaigns took place in July and August. The permanent GPS surveying will bring such information in the future, together with other techniques like radar interferometry.

Consideration of the vertical movement history prior to the period of pumping allows discrimination between these effects. Lai et al. [13] quantified 


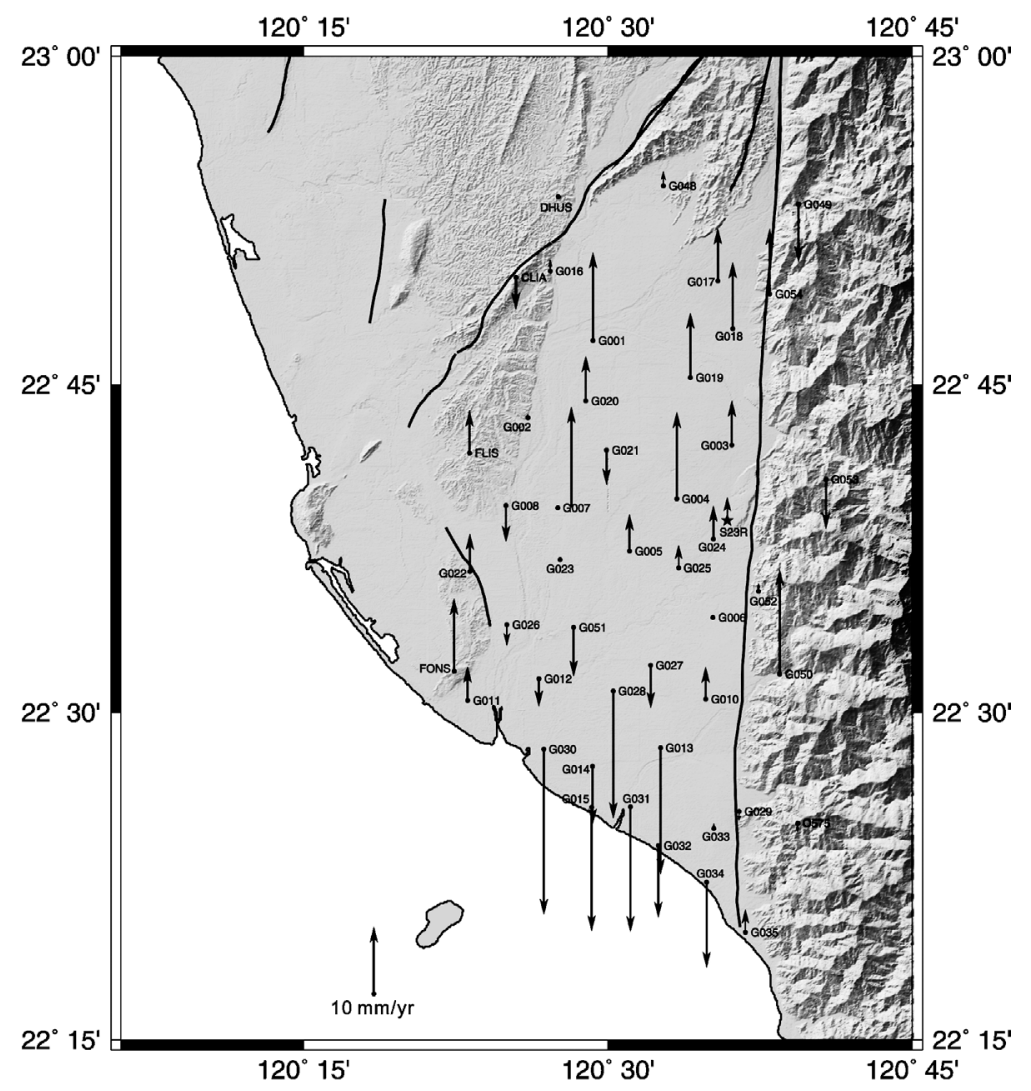

Fig. 3. Vertical velocities of GPS stations in the Pingtung Plain, from 1996 to 1999. Upward and downward-directed arrows respectively indicate uplift and subsidence. Other symbols and explanations: see Fig. 2.

Fig. 3. Vitesses de déplacement vertical des stations GPS de la plaine de Pingtung, de 1996 à 1999. Les flèches vers le haut indiquent un soulèvement, celles vers le bas une subsidence. Autres symboles et explications : voir Fig. 2.

Holocene subsidence rates in the southern Pingtung Plain, based on radiocarbon dating and using drilling cores. Based on their study, the average subsidence rate was about $4 \mathrm{~mm} \mathrm{yr}^{-1}$, the largest subsidence rates being found in the axis of the plain near the coast, like in the present-day (Fig. 4). This Holocene longterm average subsidence rate in the southern Pingtung Plain is about 2-6 times smaller (4 on average) than the subsidence rate derived from our 1996-1999 GPS measurements.

In the coastal Pingtung Plain, the present-day decrease in groundwater level and the ongoing transtensional deformation related to tectonic extrusion in southwest Taiwan concurred to produce the rapid regional subsidence observed in 1996-1999. Assuming a relatively stable tectonic component, we infer that during these four years the contribution of pumping to the subsidence of this area was about $12 \mathrm{~mm} \mathrm{yr}^{-1}$ on average, three times larger than tectonic subsidence (4 $\mathrm{mm} \mathrm{yr}^{-1}$ on average).

\section{Conclusion}

Four years of GPS measurements have shown that the horizontal deformation of the PingtungKaohsiung area is dominated by transtensional crustal deformation associated with tectonic extrusion. With respect to a permanent station of the stable continental shelf, the horizontal station velocities range 31$54 \mathrm{~mm} \mathrm{yr}^{-1}$ in the azimuth $247-273^{\circ}$ (Fig. 2). The southward increase in extensional deformation is con- 


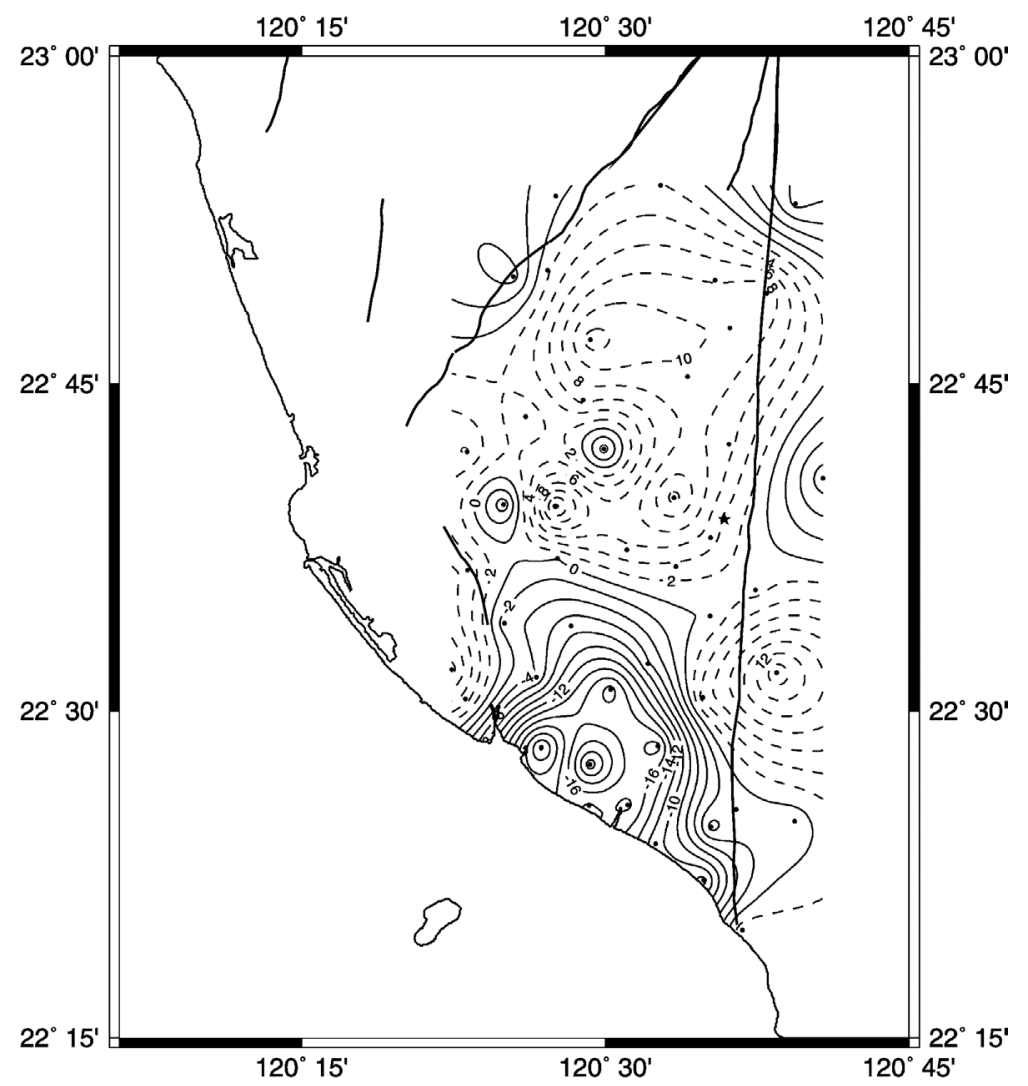

Fig. 4. Contour map of vertical velocities of GPS stations in the Pingtung Plain area, from 1996 to 1999 . Contour interval: $2 \mathrm{~mm} \mathrm{yr}^{-1}$. Dotted contours indicate uplift, solid contours indicate subsidence. Additional explanation: see Figs. 2 and 3.

Fig. 4. Carte en courbes isocines des vitesses verticales des stations GPS de la plaine de Pingtung, de 1996 à 1999. Equidistance des courbes : $2 \mathrm{~mm} \mathrm{an}^{-1}$. Les courbes pointillées indiquent le soulèvement, les courbes continues la subsidence. Explications complémentaires : voir Figs. 2 et 3 .

sistent with a lateral escape hypothesis. Uplift prevails in the northern Pingtung Plain, with velocities up to $+13 \mathrm{~mm} \mathrm{yr}^{-1}$, consistent with collision in the Taiwan belt. In contrast, twenty stations show rapid subsidence in the southern Pingtung Plain near the coast (Fig. 4), with rates that average $-16 \mathrm{~mm} \mathrm{yr}^{-1}$ and reach $-25 \mathrm{~mm} \mathrm{yr}^{-1}$. The comparison with the pattern of Holocene subsidence rates (about $-4 \mathrm{~mm} \mathrm{yr}^{-1}$ in the same area) suggests that about $75 \%$ of this subsidence result from decreasing groundwater level induced by over-pumping. The human factor thus adds major local contribution to the natural risk that results from tectonic subsidence associated with tectonic extrusion and lateral escape at the southern tip of the Taiwan collision belt.

\section{Acknowledgements}

This research was supported by the National Science Council of Taiwan (grant NSC-91-2119-M002-020) and the Central Geological Survey (grant MOEA-92-1406-33-A-00-00-00-00). It is part of the France-Taiwan cooperation (IFT-NSC-CNRS Pics Taiwan). We benefited from discussions with Chia-Yu Lu, Hao-Tsu Chu, Jian-Cheng Lee, Erwan Pathier and Benoît Deffontaines.

\section{References}

[1] J. Angelier, J.C. Lee, H.-T. Chu, J.-C. Hu, C.-Y. Lu, Y.-C. Chan, T.-J. Lin, Y. Font, B. Deffontaines, Y.-B. Tsai, Le séisme 
de Chichi (1999) et sa place dans l'orogène de Taiwan, C. R. Acad. Sci. Paris, Ser. IIa 333 (1) (2001) 5-21.

[2] H.-F. Chen, Crustal uplift and subsidence in Taiwan: an account based upon retriangulation results, Spec. Publ. Central Geol. Surv. 3 (1984) 127-140.

[3] K.-L. Fan, Some coastal environmental problems in Taiwan, Acta Oceanogr. Taiwan 39 (2001) 1-10.

[4] Forestry Bureau, MOEA (Ministry of Economic Affaires), Study on the subsidence of land in coastal areas in Pingtung county, 1987, $77 \mathrm{p}$.

[5] G.L. Hix, Land subsidence and ground water withdrawal, Water Well J. 49 (1995) 37-39.

[6] S.-K. Hsu, Plan for a groundwater monitoring network in Taiwan, Hydrogeol. J. 6 (1998) 406-415.

[7] J.-C. Hu, J. Angelier, S.-B. Yu, An interpretation of the active deformation of southern Taiwan based on numerical simulation and GPS studies, Tectonophysics 274 (1997) 145-169.

[8] J.-C. Hu, S.-B. Yu, J. Angelier, H.-T. Chu, Active deformation of Taiwan from GPS measurements and numerical simulations, J. Geophys. Res. 106 (2001) 2265-2280.

[9] U. Hugentobler, S. Schaer, P. Fridez, Bernese GPS software, Version 4.2, Astronomical Institute, University of Berne, Switzerland, 2001, $515 \mathrm{p}$.

[10] C.-H. Kuo, Y.-C. Chan, C.-H. Wang, Subsidence: over withdrawal groundwater, tectonic or both?, EOS Trans. AGU, Fall Meet. Suppl. Abstr. 82 (47) (2001) F479.

[11] O. Lacombe, F. Mouthereau, J. Angelier, B. Deffontaines, Structural, geodetic and seismological evidence for tectonic escape in SW Taiwan, Tectonophysics 333 (2001) 323-345.
[12] O. Lacombe, F. Mouthereau, B. Deffontaines, J. Angelier, H.-T. Chu, C.-T. Lee, Geometry and Quaternary kinematics of fold-and-thrust units of southwestern Taiwan, Tectonics 18 (1999) 1198-1223.

[13] T.-H. Lai, M.-L. Hsieh, P.-M. Liew, Y.-G. Chen, Holocene rock uplift and subsidence in the coastal area of Taiwan, EOS Trans. AGU, Fall Meet. Suppl. Abstr. 83 (47) (2002) F1280.

[14] A.T. Lin, A.B. Watts, Origin of the west Taiwan basin by orogenic loading and flexure of a rifted continental margin, J. Geophys. Res. 107 (B9) (2002) 2185-2203.

[15] S.-H. Liu, C.-W. Lin, W.-S. Shang, C. Liu, The effect of clay dehydration on land subsidence in the Yun-Lin coastal area, Taiwan, Environ. Geol. 40 (4-5) (1999) 290-296.

[16] MOEA (Ministry of Economic Affairs), The execution of land subsidence prevention and reclamation plan in 1997, MOEA, Taipei, Taiwan, 298 p. (in Chinese).

[17] H. Sun, D. Grandstaff, R. Shagam, Land subsidence due to groundwater withdrawal: potential damage of subsidence and sea level rise in southern New Jersey, USA, Environ. Geol. 34 (4) (1999) 290-296.

[18] A.M. Wilson, X. Gorelicks, The effects of pulsed pumping on land subsidence in the Santa Clara Valley, California, J. Hydrol. 174 (1996) 375-396.

[19] S.-B. Yu, H.-Y. Chen, L.-C. Kuo, Velocity field of GPS Stations in the Taiwan area, Tectonophysics 274 (1997) 41-59. 